DOI https://doi.org/10.36059/978-966-397-162-9/160-187

\title{
INSTITUTIONAL NATURE OF THE TAXES AND THE FISCAL CONVERGENCE, AS A PHILOSOPHY OF THE TAX SYSTEM PUBLIC ADMINISTRATION
}

\section{Krushelnytska Taisiia}

\section{INTRODUCTION}

The evolution of taxes and their transformation into the main source of state revenue both creates an opportunity and poses the task of studying their nature, economic meaning and principles of application in dynamics and in accordance with the development of society.

Integration processes caused by the globalization of the world economy at the end of the XX century - beginning of the XXI century, became a civilizational source of a significant change in the theoretical views on the nature of taxes, illuminating them in a new light. At the same time, throughout the twentieth century (up until Ukraine gained independence in 1992) the tax system in Ukraine was in decline in both theoretical and practical aspects. In the Soviet times, the economic laws were violated, the corresponding state tax institutions were destroyed, which became a difficult theoretical and institutional legacy. In a significant respect, this has become a major factor in slowing down the development of the tax system's public administration in Ukraine today. Therefore, the theoretical redefinition of the taxes' meaning in institutional and status respect within the contemporary public management is an important scientific challenge. It has become especially relevant in the context of the economic and political crisis in Ukraine.

The theory of taxes arose and developed simultaneously with the taxes themselves. The concept of "tax", which has its roots in the depths of centuries, arose even before commodity-money relations, evolved along with the development of the state and the formation of the economically administrative architecture of society. Although the 
theory of taxes emerges in the works of ancient philosophers, for example, Plato ${ }^{1}$, a modern scientific understanding of the nature of taxes is based on classical theoretical views, formed around the $18^{\text {th }}$ century. In addition, as early as at the beginning of the XVIII century both the practice of applying taxes and also the theoretical understanding of their nature and role as an effective instrument of public administration were already systematically represented.

Theoretical understanding of the concept of tax has evolved over the following centuries. Nowadays it lies at the basis of the modern paradigm of tax theory and public administration of the tax system. The honorary creators of the doctrine of taxes of the past (M. Nitti, V. Petty, F. Panteleoni etc.) and contemporaries (P. Samuelson, E. Seligman, M. Friedman and many others) established many scientific schools, that considered the category of taxes from their own angle. However, all of them agree that the nature of taxes is complex and multifaceted and is defin by the laws of reproduction. Their views touched upon philosophical, economic, social, and legal aspects of taxes. The modern theoretical, scientific, practical and legal perception of the diverse nature of the concept of "tax" varies from the philosophical concept to an objective economic category, to institutional norms of public administration and public relations, depending on taxpayers and the state. At the same time, one should take into account the fundamental dualism of the nature of taxes: they act both as a method and as a source of state revenue.

In the course of the study of the nature and modern content of the category "tax", we tried to follow the logic of gradual and consistent penetration into the essence of the phenomena and processes that took place during the formation of the statehood.

Under the influence of the evolution of public administration, the role of taxes and theoretical ideas about them changed. Today, according to the concept of new public management, taxes are

${ }^{1}$ Платон Государство. пер. с древнегреческ. - Собр. соч. в 4-х т. М. : Мысль, 1994. - Т. 3. - С. 57-64. (Серия «Философское наследие»). 
becoming an institutional norm. They have transformed from a tool of pure coercion into a tool of public welfare. The study of this transformation and the definition of the new role of taxes in public administration and in the real sector of economy make the relevance of this article.

The purpose of this article is to justify the institutional nature of the tax in the context of the concept of a new public administration and the definition of fiscal convergence as a philosophy of modern tax relations.

The role of taxes and theoretical ideas about them have been changing simultaneously with the evolution of public administration. Nowadays, according to the concept of a new public management, taxes acquire the status of an institutional norm. They transformed from an instrument of pure coercion into an important element of social welfare. The study of this transformation, the definition of the new role of taxes in public administration, and in the real sector of the economy determine the relevance of this article.

The aim of this study is to analyze the institutional nature of tax in the context of new concept of public administration, as well as definition of fiscal convergence as a philosophy of modern tax relations.

\section{Evolution of the institutional content of taxes}

The study of the history of civilization testifies that taxes are rather a late form of government revenue. First of all, they were not of a regular or permanent nature, they were levied occasionally in empirically determined amounts. The necessity to pay taxes led to the discontent among the population because it was widely thought that taxes contradicted the principle of the inviolability of private property. People believed that the taxes could be collected in exceptional cases as a temporary source of public revenue in a critical situation for the ruler or the state.

Nowadays taxes are associated with the withdrawal of individual revenues, their accumulation in the national fund, and socio-economic and administrative and political relations. As early 
as in the first half of the $17^{\text {th }}$ century the English Parliament did not recognize permanent taxes on public needs, but over time, due to the need to cover public needs, the taxes have evolved from a temporary to a permanent source of public revenue. There are no earlier periods.

Gradually, taxes become a common source of replenishment of state budgets. However, the taxes became especially popular with the advent of the developed market economy. It is in those conditions, that the tax system, typical for any contemporary state was created. Also during that period the taxes became the main source of the state revenue and were transformed into the most vulnerable and contradictory element of the economic, fiscal and legal relations between the state and taxpayers, requiring constantly growing efforts to control and manage them.

The constant quest for the optimal variants and forms of taxes and mechanisms of their collection illustrates the transformation from the origin to become a value. Thus, the evolution of the perception of taxes' meaning fluctuated between conflicting statements: from the well-known view of tax as a permitted form of robbery (according to F. Aquinas ${ }^{2}$, to their inevitability as death (according to B. Franklin ${ }^{3}$. S. Montesquieu, in turn, famously stated that nothing requires so much wisdom and intelligence as the definition, which part of earnings should be taken away from the citizens (taxes) and which should be left ${ }^{4}$. It is to be stressed, that the taxes emerged as a necessary link in economic relations in society simultaneously with the birth of the State. As K. Marx put it, taxes remain unquestionably "... the economically expressed existence of the state"

2 Словник економічної афористики / уклад.: А. Г. Загородній, Г. Л. Вознюк. - Львів: Видавництво Львівської політехніки, 2013. С. 257.

3 Якушик І. Д. Податки в країнах світу. Довідник. К.: Леся, 2004. 479 с.

4 Монтексьє Ш. Избранные произведения в 2-томах; под. ред. М. П. Баскина. М. : гос. Изд-во Полиграфической литературы, 1955. С. 31.

${ }^{5}$ Маркс К., Енгельс Ф. - Соч. - 1987. 2 изд. Т. 4. С. 308. 
Between its emergence in the ancient world and the classical concept in the XIX century, the taxes were predominantly understood as a nonequivalent payment to the state. However, since the middle of the XIX century, the taxes started being understood as a public payment for the execution of the state's functions. Such a transition became possible only through the transformation of the social system, creation of a system of socially democratic values, the emergence of the perception of the state as being responsible before the citizens. In other words, the evolution of the understanding of taxes in the theory of public administration was caused by the practical need of society to harmonize the relations between the state and its citizens and consider both elements to be part of the dynamic system, sensitive to the external changes.

Smith was among the first theorists to contribute to the development of the theoretical meaning of the concept of "tax". In The Wealth of Nations (1770) he noted that tax is a burden imposed by the State in the form of a law that stipulates its amount and procedure of payment ${ }^{6}$. Later, taxes began to be considered as a redistribution of the public national product. This view was justified by the fact that the amount of taxes depends on the conditions of the creation of the total income of society. Hence, the nature of taxes should not be limited only to the formation of budgetary resources, so the logical chain of tax participation in public reproduction should be extended. Smith emphasized that taxes are necessary to satisfy such public goods as defense, ensuring the safety of citizens and their property, education and only in isolated cases - to ensure the implementation of contracts ${ }^{7}$. The theory of social reproduction, which is based on the doctrine of K. Marx ${ }^{8}$, considered taxes exclusively as a part of the value of goods, which needs to be nullified for the reproduction of society.

6 Смит А. Исследование о природе и причинах богатства народов. Антология экономической классики в 2-х т. М. : Эконов, 1993. Т. 1.С. 37-39.

${ }^{7}$ Ibid. C. 37.

${ }^{8}$ Маркс К., Енгельс Ф. - Соч. - 1987. 2 изд. Т. 4. С. 308. 
Stiglitz believed that the taxes allow the state to perform its functions, forming hereby an individual price of tax as a tax payment. The individual is forc to make it in the form of tax payments? ${ }^{9}$.

V. Andrushchenko believes that the complexity of the scientific understanding of the nature of the tax is a consequence of the multidimensionality of the phenomenon itself, which reflects the mixture of economic, social, political, regulatory, moral, ethical, social and psychological properties ${ }^{10}$. In the XIX century, M. Alekseenko noted that, on the one hand, the tax is one of the elements of distribution and pricing policy, and on the other hand - it is one of the functions of the state ${ }^{11}$. If we reflect on this thesis, it becomes evident, that taxes provide the state with the opportunity to perform its inherent functions and their justice, or, conversely, injustice depends on the degree of development of democratic forms in the state and tax culture of citizens.

However, the definition of the of taxes as the price of state services implies, in our view, that the equivalent, reverse nature of tax relations is not a single act of tax payment (and receipt of benefits), but a regular repeated operation, carried out at the macroeconomic level. The state in this sense acts as a personified economic entity.

Therefore, it is quite a common view that taxes are a payment for indivisible public services provided by the state. The discussion around this definition began at the end of the 19th - beginning of the 20th centuries and was developed by D. Mill, F. Nitti, P. Samuelson, Jean S. de Sismondi and other prominent scientists. Thus, Jean

9 Stieglitz Joseph E. Economics of the public sector. New York / London : W. W. Norton\& company. 2000. URL: http://www.ebay.com/ctg/economics-publicsector-joseph-e-stiglitz-2000-hardcover-subsequent-edition-/118991.

10 Андрущенко В. Л. Морально-етичні імперативи податків та оподаткування (західна традиція). Монографія. К.: Алерта. 2013. С. 32-33.

11 Алексеенко М. М. Взгляд на развитие учения о налоге у экономистов А. Смита, Ж.-Б. Сея, Риккардо, Сисмонди и Д. Миля. Москва : Издательская груnпа URSS, Изд. 2. Серия: Классика политэкономической мысли. 2012. С. 65. 
Simonde noted that the tax is the value paid by a citizen for the enjoyment with public order, justice, personal liberty and property rights ${ }^{12}$. The author considered that taxes cover the annual expenses of the State, and each taxpayer thus contributes to the total expenses incurred for him and other citizens ${ }^{13}$.

The German financial expert Neumann, on the other hand, refers to taxes as "... payments, introduced to generate income for the State and communities since the latter are not rewarded for the special services..." 14 . In other words, scientists have not reached a consensus on the essence of the tax, even when we speak about its narrow definition through socially relevant services.

D.Ricardo considered taxed from another perspective: he believed that taxes should be used only for fiscal purposes because they hinder the process of formation and accumulation of capital, and therefore the best tax is the least tax ${ }^{15}$.

Representatives of the German school (L. Stein and W. Sombart) considered taxes from a different angle: according to their theory, taxes represent the productive consumption of capital ${ }^{16}$. Thus, in particular, L. Stein considered the tax as a production expense - each tax is included in the costs of production of the goods and thus transferred to all consumers, this tax is returned to the citizens in the form of public services and increasing labor productivity ${ }^{17}$. V.Pushkareva also shares the views of the classical representatives of

12 Сисмонди Симонд де Жан-Шарль-Леонард. Новые начала политической экономии или о богатстве в его отношении к народонаселению. Москва. Госиздат, 1937. 386 с.

13 Ibid.

14 Ярошенко Ф. О., Павленко В. В., Павленко В. П. Історія податків та оподаткування в Україні. Навч. посіб. за заг. ред. А. М. Подоляки. К.: ДП «Вид. дім «Персонал». 2012. С. 8.

15 Рикардо Д. Начала политической экономии и налогового обложения. Антология экономической классики в 2-х т. М. : Эконом, 1993. Т. 1. С. 397.

16 Суторміна В. М., Федосов В. М., Андрущенко В. Л. Держава податки - бізнес (зі світового досвіду фіскального регулювання ринкової економіки). Монографія. К. : Либідь, 1992. С. 11.

${ }^{17}$ Ibid 
the economic theory ${ }^{18}$. She considers the economic nature of the tax from the perspective of the theory of price and the theory of supply in determining the source of taxation (capital, income) and the impact of the tax on private firms and the economy in general. Therefore, she believes that the economic nature of the tax resides in the sphere of production and distribution ${ }^{19}$.

At the beginning of the XIX century such scientists as I. Kulisher, I. Ozerov, V. Tverdokhlebov, M. Turgenev) considered taxes as an instrument of economic and social reforms. In their view, it is used by the state for redistribution of property, support of certain and development of other forms of management as means to achieve some social or governmental goal ${ }^{20}$. We consider the latter statement to be true, but not sufficient to highlight the multidimensional nature of taxes.

A separate group of scientists considers the tax as a set of relations between the state and taxpayers (Y. Lytvynenko, E. Milyavska, V. Oparin etc.). Thus, for example, according to the definition of J. Litvinenko, taxes are an obligation, a compulsory payment, which exists in the economic basis and within economic relations $^{21}$.

V. Oparin believes that "... the economic content of taxes reflects the financial relations between the state and taxpayers to create a national centralized fund of funds necessary for the state to perform its functions" $"$. B. Vishnevsky and A. Vetkin defined taxes as “... a

${ }^{18}$ Пушкарева В. М. История финансовой мысли и политики налогов. М. : Финансы и статистика, 2001. С. 208.

19 Ibid.

20 Кулишер И. М. Очерки финансовой науки. Вып. 1. Петроград: Книгоиздительство «Наука и школа». 1919. С. 66.

21 Літвіненко Я. В. Податкова політика. Навч. посіб. К.: МАУП, 2003. C. $17-18$.

Опарін В. Фінансова система України (теоретико-методологічні аспекти). Монографія. К. : КНЕУ. 2005. С. 136. 
specific product of the development of public relations",23. It should be noted, that the Western scientists usually do not analyze the "tax relations" - this approach is most typical in the scientific Soviet and post-Soviet period and space. Of course, we do not deny the right to existence of the concept of "tax relations", especially given the heterogeneity of the nature of taxes, but we consider the tax system, the determining element of which are taxes, as a set of economic and legal relations.

With the development of the state and social relations, scientific views on the nature and essence of taxes narrowed down to the vision of their mandatory payment to the budget. For example, O.Vasilik defines taxes as mandatory payments, which are taken by the state from the income of legal entities or individuals to the corresponding budget to finance the state's expenditures, with the process being regulated by the constitution and other legislative $\operatorname{acts}^{24}$. At the same time, he emphasizes that taxes can be considered as the method of equalization of income of legal entities and individuals and serve as feedback with the taxpayers via the financing of relevant expenses. The latter statement, in our opinion, is true only in an abstract sense.

Discussion of theoretical views on the nature of the tax does not stop today. However, as a result of the evolution of tax theory and the gradual transformation of the role of the state in the regulation of the economy, the tax obtains several specific features. Such traits as unilateralism of the tax, coercive nature, coverage of costs for the performance of functions and the like are reflected in the most of the thematic scientific publications of the late XIX, early XX century. These features in the definitions of tax in scientific developments have become permanent and mandatory. In the table below we present a

23 Налогообложение: теории, проблемы, решения. Монографія / В. П. Вишневский, А. С. Веткин, Е. Н. Вишневская и др.; под. общ. ред. В. П. Вишневского. Донецк: ДонНТУ, ИЭП НАН Украины, 2006. С. 62.

24 Василик О. Д. Податкова система України. Навч. посіб. К. : Поліграфкнига, 2004. С. 43. 
snapshot of the scientific views on the concept of taxes, as a consistent and compulsory payment, ranging from a somewhat sharp, in our opinion, the vision of E. Seligman, R. Strum ${ }^{25}$ and ending with the definition of V. Panskov ${ }^{26}$. The latter, which has become quite widespread, considers the taxes as unrequited payment, which does not presuppose any response (i.e. fulfillment of specific functions) from the state.

Global processes (international economic integration, in particular) contributed to the emergence of conceptually new views on taxes, which came into contradiction with the theory of collective needs, formulated as early as the end of the XIX century - beginning of the early 20th century (Table 1).

Thus, F. Nitti believed that the tax is a certain amount of wealth citizens give to the state and local authorities to meet the collective needs ${ }^{27}$. A. Bukovetsky, A. Ganzel, and others were among the Russian scientists adhering to this theory ${ }^{28}$. It should be noted, that it is the theory of welfare, which today is dominant in the theoretical understanding of the taxes, has radically changed the views of scientists. Beginning from the end of the XX century, the Western theoretical tradition inextricably linked taxes to the concepts of the public good, public choice, reorientation to the interests of the individual, while also studying external and internal effects of public administration of the tax system. As a result, there is a need for an explanation of the causes, consequences and methods of elimination of such phenomenon as tax evasion.

${ }^{25}$ Селигман Э., Стурм Р. Этюды по теории обложения: пер. студентов В. Гефдинга и Б. Никольского. Под. ред. и с предисловием проф. М. И. Фридмана. СПб. 1908. 231 с.

26 Павлюченков С.А. Орден меченосцев. Партия и власть после революции. 1917-1929. Монография. Собрание, 2008. 464 с.

${ }^{27}$ Нитти Ф. Основны начала финансовой науки: Перевод съ итальянского И. Шрейдера ; под редакцией и съ дополнениями А. Свирщевского. М. : Издание М. ис, Сабашниковыхъ, 1904. 623 с.

${ }^{28}$ Буковецкий А. И., Гензель П. П., Кулишер И. М., Твердохлебов В. Н. Налоги в иностранных государствах. М. Финансовое издательство НКФ СССР. 1926. 312 c. 
Definition of tax compulsory and mandatory payment

\begin{tabular}{|l|l|}
\hline \multicolumn{1}{|c|}{ Source } & \multicolumn{1}{c|}{ Definition of tax } \\
\hline E. Seligman, Strum $^{29}$ & $\begin{array}{l}\text { Mandatory payment, gathered by state from } \\
\text { individuals for covering expenses, related to } \\
\text { the nation-wide needs. The specific benefits } \\
\text { of taxpayers are not presupposed. }\end{array}$ \\
\hline A.A. Isayev & $\begin{array}{l}\text { Mandatory cash payments by private } \\
\text { households that cover the total costs of the } \\
\text { state and local government units }\end{array}$ \\
\hline $\begin{array}{l}\text { B.B. Buryakovski, } \\
\text { S. Kalambet }{ }^{31}\end{array}$ & $\begin{array}{l}\text { The mandatory payment established by the } \\
\text { supreme body of state legislative power, } \\
\text { which individuals and legal entities pay to } \\
\text { the budget in the amounts and within the } \\
\text { time limits prescribed by law. }\end{array}$ \\
\hline B.Г. Panskiv ${ }^{32}$ & $\begin{array}{l}\text { Mandatory, individually irrevocable, } \\
\text { relatively regular and legislatively payment, } \\
\text { established by the state and paid by } \\
\text { organizations and individuals to financially } \\
\text { support the activities of the state and } \\
\text { municipalities. }\end{array}$ \\
\hline
\end{tabular}

In such a way, the evolution of the scientific understanding of the taxes had several stages of development. Below we will list seven stages identified by E. Seligman as early as in 1998 (we present them with the generalization of N. Goritskaja):

${ }^{29}$ Селигман Э., Стурм Р. Этюды по теории обложения: пер. студентов В. Гефдинга и Б. Никольского. Под. ред. и с предисловием проф. М. И. Фридмана. СПб. 1908. 231с.

${ }^{30}$ Исаев А. А. Очерк теории и политики налогов. М. : ООО «ЮрИнформ Пресс». 2004. 270 c.

31 Буряковский В. В., Кармазин В. А., Каламбет С. В. Налоги. Учебное пособие. Днепропетровск : Пороги, 1998. 611 с.

32 Пансков В. Г. Российские налоги. Нужна научная основа. Российский экономический журнал. 1993. № 3. С. 12. 
- at the very first stage, the idea of the donation was dominant (in the Middle Ages, it was considered, that the tax is an individual gift to the government);

- at the second, the government itself has humbly asked the people for support;

- at the third stage it was believed that the citizens assisted the state in fulfilling its functions;

- at the fourth stage the idea emerged, that the individuals make a sacrifice in the interests of the state;

- at the fifth stage, the payer of taxes is thought to proceed from the sense of duty and responsibility;

- at the sixth stage it is believed, that the state coerces the individuals to pay taxes;

- at the last, seventh stage, the idea came up, that the state deducts a certain calculated amount from the salary of the citizens, independent from their approval ${ }^{33}$;

- we would add the eighth stage, where the tax is considered as a source for satisfying collective needs, so it combines both voluntary and forced characteristics.

By the end of the $20^{\text {th }}$ - beginning of the 21 st centuries, the development of tax theory reached a new stage. In other words, today we can talk about the ninth stage of evolution in the understanding of the nature of taxes, the main contributors to which are the supporters of institutionalism. Thus, the institutional theory defines the tax concerning the payer as (1) mandatory; (2) voluntary; (3) compulsory payment ${ }^{34}$. The behavior of taxpayers could be determined by three motivations, but the task of public administration is to determine the optimal ratio between them. In the majority of countries with developed economies and established democratic legal traditions, the second and third motivations

33 Горицкая Н. Подоходный налог с граждан: будущее в прошедшем. Налоговое право. № 5. 1999. С. 22.

34 Андрущенко В. Л. Морально-етичні імперативи податків та оподаткування (західна традиція). Монографія. К.: Алерта. 2013. 214 с. 
prevail, while in Ukraine and other CIS countries the first and third, respectively, are dominant. This trend can be explain by the fact, that the taxation and the public awareness of its necessity started being formed only in the $90 \mathrm{~s}$.

Nowadays, amid the intensification of globalization processes and associated international economic integration, we witness a formation of a motivational society with a focus on the needs of the individual. We should also add that the formation of the state tax policy is increasingly influenc by the factors of irresistible force: tax competition, the growth in prosperity in neighboring countries, the need to solve social problems, the desire to equalize the tax burden and the like. Therefore, the interpretation of the coercive nature of taxes is constantly subjected to scientific criticism, freeing up space for their voluntary and mandatory nature interpretations. Thus, Richard Musgrave proposed an alternative concept of voluntary fiscal exchange with the following scheme: taxes are paid in exchange for public and social benefits provided by the state ${ }^{35}$. Today, scientists (V. Vishnevsky, A. Vetkin, etc. ${ }^{36}$ ) increasingly propose to consider taxes as both voluntary payments (payment in exchange for public goods) and compulsory (payers give away part of their resources for external purposes).

We support the position of L. Andruschenko, who argues, that the willingness to pay taxes in society is the result of responsibility of citizens, supplemented by the corresponding law system, accepted by the power representatives ${ }^{37}$. We would also add that social benefits, created by the public power are another

35 Musgrave R. A. The Voluntary Exchange Theory of Public Economy. Quarterly Journal of Economics. 1939. Vol. 53. P. 213-237.

36 Вишневский В. П., Веткин А. С., Чекина В. Д., Виецкая О. В., Вишневская Е. Н. Формирование и реализация налоговой политики в сфере управления развитием промышленности. Монография. НАН Украины, Ин-т экономики пром-сти. Донецк, 2014. С. 60.

37 Андрущенко В. Л. Фінансова думка Заходу в XX столітті (Теоретична концептуалізація i наукова проблематика державних фінансів). - Львів : Каменяр, 2000. 303 с. 
important motivational force. This thesis once again proves that the tax in a democratic state of the XXI century governed by the rule of law can be considered neither a purely voluntary nor a purely mandatory payment.

However, the question about the voluntary or compulsory nature of taxation refers to all spheres of an individual's existence, that is, not only economic and political but also social, psychological, mental, etc. The taxpayer should understand and recognize the complex process of the redistribution of public goods, which is carried out through taxation. To a certain degree, this mechanism allows mitigating the unevenness of the material conditions of the existence of other individuals through equal access to the benefits of collective consumption and providing the opportunity to use the benefits of market or individual consumption.

However, for the majority of taxpayers, such philosophical reasoning about the benefits and taxes they receive is too onerous. Moreover, both the poor quality of public services and bureaucratization of tax institutions in Ukraine undermine the authority of the state itself, which makes it less likely, that the citizens will be motivated to pay taxes voluntarily. We would like to emphasize that it is the motivation of voluntary payment of taxes, as a socially conscious justification of the entire process of taxation that ensures the progressive development of society. The readiness of tax bearers to pay the taxes voluntarily is a phenomenon, which is very likely to occur in case of a long-term consistent formation of an appropriate outlook, strengthened by the real use of public goods. We call this a tax culture of citizens.

Tax culture is an element of long-term state tax policy. It results in the formation of a system of norms, rules of conduct, and worldviews that make tax evasion impossible. Its formation takes a long time and demands implementation of a multidimensional approach (nurturing, promotion, the introduction of regulatory incentives or restrictions, etc.). Still, it is possible to nurture the tax culture for a duration of hundred years and it will not take a leading position in the society as an institutional norm if the taxes are not 
materialized into the public good. This is especially noticeable in Ukraine, a country where there is a war, and citizens want the funds withdrawn from their salaries as taxes to be invested in defense, security, and development areas.

Summarizing, we can identify two leading approaches to the theoretical justification of the category "tax" in the history of science. The former is based on the recognition of the mandatory nature of taxes and was historically based on incentive and coercive methods of tax collection. Gradually the procedure of tax collection transformed from the tough measures to softer, more civilized forms. The latter, in turn, defined tax as a duty of citizens and relied on the voluntary nature of the tax. It can be considered a result of the evolution of a democratic society, the growth of the authority of the state and the increase in individual awareness of the necessity of paying the taxes.

Analysis of the concept of "tax", from its philosophical sources to the formation of legislative norms and the mechanism of practical implementation of taxation allows us to consider the theoretical essence of taxes through the prism of their institutional and status characteristics (See Fig. 1).

We believe that the tax should be seen as a unique institutional norm the nature of which is multifaceted and contradictory. At the same time, the institutional characteristic of the tax resides in its exclusive role in the process of influencing public production, and the distribution of public goods, which is carried out through taxation. It allows mitigating the unevenness of the material conditions of individual and social existence in a certain way.

In such a way, we define taxes as a heterogeneous, unique, institutional norm of public administration of voluntary and compulsory nature. It is calculated proceeding from the socioeconomic development of the country, is used in the process of redistribution of public goods, provides the formation of budget income and enables the reduction of inequality of social and material conditions. 


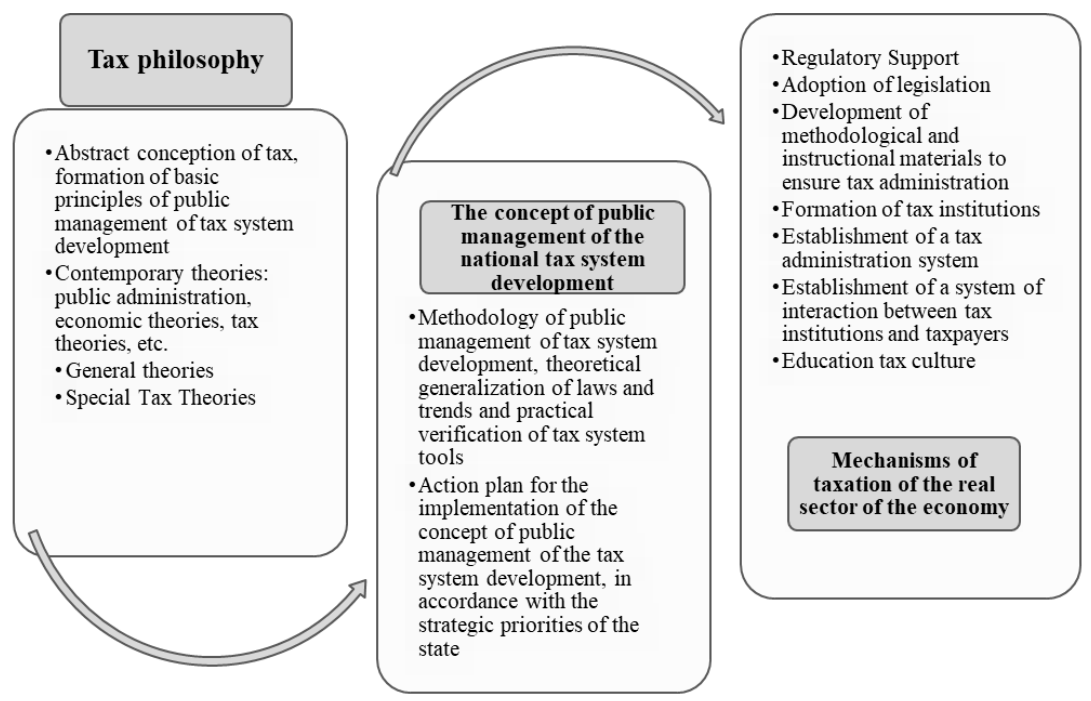

\section{Fig. 1. The logic of determining the essence of the category "tax"}

Institutional nature of the tax is manifested in its fullest form through the awareness of the role of public administration of the tax system, the use of state tax levers and regulation of tax relations.

\section{Fiscal convergence as a philosophy of public administration of tax systems}

When considered from the point of view of tax relations regulation in the country and abroad, the state management of the tax system in different countries gradually relies on conceptual approaches aimed at uniting the interests of all participants of the tax process: the state, taxpayers and tax bearers (individuals and legal entities). Considering, that it is necessary to take into account the individual needs and peculiarities inherent in the modern stage of civilization development, further unification of the interests of the participants of the tax process and their desire to balance the possible benefits and available resources becomes a natural and predictable phenomenon, which gradually turns into an intra-national fiscal convergence. 
Nowadays the fiscal convergence is considered merely in the international aspect, which is important, but not sufficient for building an effective tax system management in the conditions of Ukraine's integration into the world economic space. Contradictions, inaccuracies, the ambivalence of tax relations between the participants of the tax process (tax institutions and subjects of taxation), imperfections and high cost of administration, etc. make it impossible to infuse the national tax system into the international one harmoniously. Therefore, progress towards integration into the international tax system should start with national fiscal convergence.

In our view, the national public administration in the area of taxes should prioritize the following: consider the possibility of extrapolating the experience of the world's leading countries to building of Ukrainian tax policy, constructing mechanisms and tools of the tax system with attention to the harmonization of tax relations, based on the application of the philosophy of fiscal convergence. Such a need is aggravated by the following fact: amid Ukraine's integration into the world economic space, the issue of regulation of social and economic relations between the participants of the tax process (that is, between the state and society) remains a permanently unresolved issue in the process of building a harmonious tax system.

We believe that the philosophy of public administration of the tax system is based on overcoming the conflict between the perception of the opponents of tax relations (the state and taxpayers), the ratio of the level of public goods provided by the state and the level of the tax burden. It is because of the growing acuteness of this contradiction that the scientists believe that " $\ldots$ the ideal of the optimal taxation is unattainable because the formation of the national tax system is usually a result of the compromise of interests between political groups ${ }^{\prime 38}$. Perhaps, taking this into account,

38 Соколовська А. М. Податкова система України: теорія та практика становлення. Монографія. К. НДФІ, 2001. С. 7. 
A. Sokolovskaya suggests building tax relations within the "corridor", which was a consequence of "the compromise achieved between the interests of various political forces ..."39. We would add to this the following thesis: the compromise, mentioned above, should be reached between all participants of the tax process. The interests of all the groups should be taken into account, and it depends on the competence of public administration to set the boundaries to the said corridor and to coordinate the public and business interests. In support of this, I would like to quote Oleg Yuldashev: “... we enter a period of systemic development of a new type of dialogue between the authorities and entrepreneurs" $" 40$. This new type of dialogue can be implemented in the form of national fiscal convergence. It was written in 2006. Today, public-private partnerships and tax policy orientation towards a common interest compromise have become common practice ${ }^{41}$.

In the complex process of tax system management, the coordinating and controlling role is played by the state tax institutions, which are part of the tax system. Entrepreneurs and individuals are outside of the direct state administration, but they are subject to regulatory requirements and are a source of tax flow. So, in our opinion, they play an important role in the process of functioning not only the tax system but also the state as a whole. On the other hand, effective management of the taxation process is impossible without the influence of the state on the subjects of taxation (and we are having in mind not only administrative and regulatory levers here). As the world practice shows, today motivational and individual approaches to the formation of tax relations are becoming more relevant.

39 Ibid.

40 Юлдашев О. Ще раз про методологію удосконалення державного управління: може, востаннє? Юридичний журнал. 2005. № 9. C. 4. URL: http://www.justinian.com.ua/article.php?id=1894.

41 Крушельницька Т. А Теоретична сутність і практичне наповнення податкового потоку як об'єкту державного управління. Державне управління: удосконалення та розвиток: електронне наукове фахове видання. Київ. 2015. № 3. URL: http://www.dy.nayka.com.ua/. 
The state should ensure a maximum inflow of funds to the budget in the form of taxes to provide certain socially useful benefits to the population. Moreover, to ensure compensation for public costs (which is one of the primary interests of the state), tax rates are increasing, and the volume of socially useful goods are gradually decreasing. That is why, to encourage citizens to pay taxes voluntarily the public administration should develop and introduce a corresponding state program and also constantly try to find a balance in the tax relations.

To ensure effective management of the tax system one should analyze the extent of the state's impact on the subjects of taxation. To do this, it is necessary to abstract somewhat from the excessive detail and variety of tax forms and, to focus on the fact that social strata of the population make the greatest contribution to the tax treasury. We fully agree with this thesis, because taxpayers happen to be the generator of the tax flow, launching it with their physical, intellectual, financial, etc. efforts. Within the tax flow generation, the function of the state administration should be to encourage the taxpayers to carry out the taxable economic operations, calculate and pay taxes.

Following P. Samuelson ${ }^{42}$ we will rely on the theory of public expenditure and its relationship with the "collective consumer goods" and use the approximation method to represent graphically the ratio of the tax burden and socially useful goods provided by the state to citizens (taxpayers). It is to be said that we consciously simplified the values and calculations for greater clarity, taking into account certain objective conditions (Fig. 2).

42 Samuelson P. A. The Pure Theory of Public Expenditures. Samuelson. Review of Economics and Statistics, 1954. Vol. 36. No. 4. P. 388. 


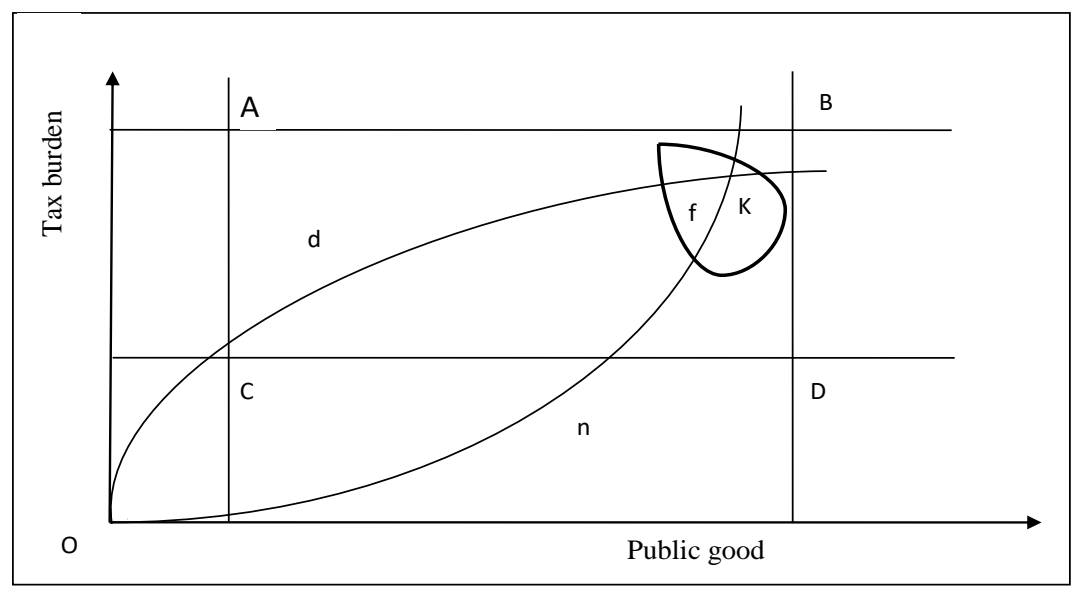

The direct $\mathrm{AB}$ corresponds to the maximum tax pressure, which increases the risk of social shifts, the expansion of the shadow economy sector, etc.

The CD corresponds to the minimum tax pressure below, within which tax revenues are not enough to cover budget expenditures.

$\mathrm{AC}$ - the level of minimum socially useful goods.

$\mathrm{BD}$ is at the level of maximum socially useful goods.

Curve $\mathrm{d}$ - tax-benefit ratio from the point of view of the state interests

Curve $\mathrm{n}$ - tax-benefit ratio from the taxpayer's point of view

Plane $\mathrm{f}$ - a correlation field of fiscal convergence, with the center at point $\mathrm{K}$, within which the level of relations "tax burden - public goods" reaches an acceptable level for all participants of the tax process

\section{Fig. 2. National fiscal convergence}

From the point of view of the public interest, the mentioned ratio corresponds to the curve $\mathrm{d}$. Of course, it is expected that the slope angle of the curve will decrease over time, as the growth of tax rates should gradually slow down (due to the risk of civil disobedience, it is impossible to raise them very quickly and indefinitely).

In addition, tax competition is an objective constraining factor of the tax rate growth, so sometimes the tax burden may have negative dynamics. The volume of socially useful goods is measured by many factors, such as the general economic development of the country, the direction of state social policy, the ratio of individual and group interests, etc. 
The volume of the socially useful goods, is a "fair share" of these interests ${ }^{43}$. This volume should gradually increase if we refer to the experience of countries with developed economies. However, this is not the case for countries whose economies are exposed to a significant impact of various crises (as is true for Ukraine): the rate of growth of this component will be somewhat slower compared to the rate of growth of the tax burden. This is particularly characteristic for the stage of elimination of the consequences of economic uncertainty, or the conditions of economic crisis, or changes in the trend of state social policy.

For taxpayers, in turn, the ratio of the tax burden to public goods will be inverse: citizens want to experience minimal tax burden and receive increasingly more public goods (curve n). However, at a certain stage of social development, taxpayers realize that in order to obtain the maximum possible benefits, to improve the standard of living as a whole, to ensure social protection, environmental safety, etc., it is necessary to pay more taxes. Therefore, with the development of public consciousness, the curve of the ratio of "tax burden to public goods" will slowly rise.

As we can see, curves $d$ and $n$ intersect twice. For the first time, at point $\mathrm{O}$, which corresponds to the pre-state period of social development, when there were no taxes or benefits. Suddenly, the curves intersect at point $\mathrm{K}$, which reflects the ideal state of development of tax relations, the hypothetical moment of complete alignment of interests of the participants of the tax process (the state and taxpayers). This moment corresponds to a highly developed society with a highly developed mentality, culture, organization, and tax system.

Yet, we are aware of the low probability of complete alignment of interests of the tax process' participants at all levels in the near future. We assume the presence of a certain correlation field (plane f)

43 Рубинштейн А. Я. К вопросу расширения «Чистой теории общественных расходов». Научный доклад. М. Институт экономики РАН. 2007. C. 16 . 
with the center at point $\mathrm{K}$, within which the level of relations "tax burden - public goods" reaches an acceptable level for all participants of the tax process.

Proceeding from this, we define the category "national fiscal convergence" as a fundamental principle of state management of the tax system of the twentieth century. It establishes the process of convergence, unification, compromise, positive complementarity and stabilization of economic and social interests of the participants of the tax process within the limits of the conditional correlation field, outlined by the ratio of public goods and tax burden.

From the point of view of regulation of tax and other social and financial relations, one of the fundamental foundations of effective state management of the tax system is the unification of the interests of all participants of the tax process (the state, economic entities, citizens), on the principles of fiscal convergence of the first level (national) with the gradual development of its second level (international), from the position of which we can talk about global tax administration.

Adaptation of the tax legislation of Ukraine to the world requirements and standards and harmonization of taxation is the main element of fiscal convergence. In order to assess the effectiveness of the functioning of the adapted tax system, it is necessary to implement certain criteria. With the use of the approximation method, it became possible to define the planes of economic interests of the state and taxpayers and conditionally determine the correlation field of their mutual interests as a desired and expected result of the development of the tax system. Proceeding from the fundamental principles of effective public administration of the tax system, it is necessary to unite the interests of all participants in the tax process (state, economic entities, citizens) on the principles of fiscal convergence of the $1 \mathrm{st}$ level (national) with its gradual development to the second level international convergence.

Based on this, we conclude that the national fiscal convergence is a process of approximation, positive complementarity, compromise, and stabilization of the interests of tax participants, 
which is implemented through the introduction of the institutional mechanism of the tax system in order to maximize the possibilities of the budget filling and the receipt of socially beneficial benefits by citizens.

\section{CONCLUSIONS}

Based on the abovesaid we are making the following conclusions:

Taxes act both as a method and as a source of state revenues, they are the result of a long historical and economic development of society, therefore the category of "tax" holds economic, philosophical and institutional meaning. The specific nature of taxes lies in the fact that the equivalent, reverse nature of tax relations is not a single act of paying a tax payment in exchange for receiving goods, but is a regular multiple procedure. The state, according to the concept of new public administration, functions as an entity.

It has been proved that the tax is a unique, institutional norm, the nature of which is multifaceted and controversial. The institutional meaning of a tax lies in its exclusive role in the process of influencing social production, and the distribution of public goods, which is carried out through taxation and allows us in a certain way to mitigate the uneven material conditions of individuals in society.

It has been found that national fiscal convergence is a process of approximation, positive complementarity, compromise, and stabilization of the interests of tax participants, implemented through the introduction of the institutional mechanism of the tax system. Its aim is to fill the budget as much as possible and obtain socially useful benefits for citizens.

In the context of globalization and international economic integration, a motivational society is emerging with a focus on the needs of the individual. Therefore, taxes as an institutional norm is an instrument for the implementation of the main priorities of the state tax policy. Those priorities are: 
- firstly, the financial aspect, according to which tax policy should provide the need for all levels of government in financial resources sufficient to implement economic and social policies and to fulfill the functions assigned to them by the authorities;

- secondly, the economic aspect, which provides the possibility of achieving sustainable economic development of the country, regions, municipalities, individual business entities. Achieving this priority is possible provided the philosophy of fiscal convergence is introduced;

- thirdly, the social aspect, which makes it possible to mitigate the inequalities in incomes arising in the process of market relations. This allows achieving the proper safety and quality of life of citizens.

\section{SUMMARY}

The article analyzes the institutional nature of tax in the contest of the concept of a new public administration and defines national fiscal convergence as a philosophy of modern tax relations.

It has been proved that taxes act both as a method and as a source of state revenue, they are the result of a long historical and economic development of society. The category "tax" holds economic, philosophical and institutional content. The tax is a unique, institutional norm, the nature of which is multifaceted and controversial. It has been proved that the institutional essence of the tax lies in its exclusive role in the process of influencing social production, and the distribution of public goods, which is carried out through taxation and allows in a certain way to mitigate the uneven material conditions of individuals in society.

It has been found that national fiscal convergence is a process of approximation, positive complementarity, compromise, and stabilization of the interests of tax participants, implemented through the introduction of the institutional mechanism of the tax system. Its aim is to fill the budget as much as possible and obtain socially useful benefits for citizens. 


\section{REFERENCES}

1. Платон Государство. пер. с древнегреческ. Собр. соч. $в$ 4-x m. М. : Мысль, 1994. Т. 3. С. 57-64. (Серия «Философское наследие»).

2. Словник економічної афористики / уклад.: А. Г. Загородній, Г. Л. Вознюк. - Львів: Видавництво Львівської політехніки, 2013. С. 257.

3. Якушик I. Д. Податки в країнах світу: довідник. К.: Леся, 2004. 479 с.

4. Монтексьє Ш. Избранные произведения в 2-томах; под. ред. М. П. Баскина. М. : гос. Изд-во Полиграфической литературы, 1955. 799 с.

5. Маркс К., Енгельс Ф. Соч. 1987. 2 изд. Т. 4. С. 710.

6. Смит А. Исследование о природе и причинах богатства народов. Антология экономической классики : в 2-х т. М. : Эконов, 1993. Т. 1. 382 с.

7. Stieglitz Joseph E. Economics of the public sector. New York / London : W. W. Norton\& company. 2000. URL: http://www.ebay.com/ctg/economics-public-sector-joseph-e-stiglitz2000-hardcover-subsequent-edition-/118991.

8. Андрущенко В. Л. Морально-етичні імперативи податків та оподаткування (західна традиція). Монографія. К.: Алерта. 2013. 214 с.

9. Алексеенко М. М. Взгляд на развитие учения о налоге у экономистов А. Смита, Ж.-Б. Сея, Риккардо, Сисмонди и Д. Миля. Москва. Издательская групnа URSS, Изд. 2. Серия: Классика политэкономической мысли. 2012. 152 с.

10. Сисмонди Симонд де Жан-Шарль-Леонард. Новые начала политической экономии или о богатстве в его отношении к народонаселению. Москва. Госиздат, 1937. 386 с.

11. Ярошенко Ф. О., Павленко В. В., Павленко В. П. Історія податків та оподаткування в Україні. Навч. посіб. за заг. ред. А. М. Подоляки. К.: ДП «Вид. дім» Персонал2. 2012. $416 \mathrm{c}$. 
12. Рикардо Д. Начала политической экономии и налогового обложения. Антология экономической классики в 2-x m. М. : Эконом, 1993. Т. 1. С. 397-460.

13. Суторміна В. М., Федосов В. М., Андрущенко В. Л. Держава - податки - бізнес (зі світового досвіду фіскального регулювання ринкової економіки). Монографія. К. : Либідь, 1992. $328 \mathrm{c}$.

14. Пушкарева В. М. История финансовой мысли и политики налогов. М. Финансы и статистика, 2001. 256 с.

15. Кулишер И. М. Очерки финансовой науки. Вып. 1. Петроград: Книгоиздительство «Наука и школа». 1919. $215 \mathrm{c}$.

16. Літвіненко Я. Податкова політика. Навч. посіб. К. МАУП, 2003. 224 с.

17. Опарін В. Фінансова система України (теоретикометодологічні аспекти). Монографія. К. : КНЕУ. 2005. 240 с.

18. Налогообложение: теории, проблемы, решения. Монографія / В. П. Вишневский, А. С. Веткин, Е. Н. Вишневская и др.; под. общ. ред. В. П. Вишневского. Донецк: ДонНТУ, ИЭП НАН Украины, 2006. 504 с.

19. Василик О. Д. Податкова система України. Навч. посіб. К. : Поліграфкнига, 2004. 447 с.

20. Селигман Э., Стурм Р. Этюды по теории обложения: пер. студентов В. Гефдинга и Б. Никольского. Под. ред. и с предисловием проф. М. И. Фридмана. СПб. 1908. 231 с.

21. Павлюченков С.А. Орден меченосцев. Партия и власть после революции. 1917-1929. Монография. Собрание, 2008. $464 \mathrm{c}$.

22. Нитти Ф. Основны начала финансовой науки: Перевод съ итальянского И. Шрейдера ; под редакцией и съ дополнениями A. Свирщевского. М. : Издание М. ис, Сабашниковыхъ, 1904. $623 \mathrm{c}$.

23. Буковецкий А. И., Гензель П. П., Кулишер И. М., Твердохлебов В. Н. Налоги в иностранных государствах. М. : Финансовое издательство НКФ СССР. 1926. 312 с. 
24. Исаев А. А. Очерк теории и политики налогов. М. ООО «ЮрИнформ - Пресс». 2004. 270 с.

25. Буряковский В. В., Кармазин В. А., Каламбет С. В. Налоги. Учебное пособие. Днепропетровск : Пороги, 1998. $611 \mathrm{c}$.

26. Пансков В. Г. Российские налоги. Нужна научная основа. Российский экономический журнал. 1993. № 3. C. 12 .

27. Горицкая Н. Подоходный налог с граждан: будущее в прошедшем. Налоговое право. № 5. 1999. С. 21-24.

28. Musgrave R. A. The Voluntary Exchange Theory of Public Economy. Quarterly Journal of Economics. 1939. Vol. 53. P. 213-237.

29. Вишневский В. П., Веткин А. С., Чекина В. Д., Виецкая О. В., Вишневская Е. Н. Формирование и реализация налоговой политики в сфере управления развитием промышленности. Монография. НАН Украины, Ин-т экономики пром-сти. Донецк, 2014. $147 \mathrm{c}$.

30. Андрущенко В. Л. Фінансова думка Заходу в $\mathrm{XX}$ столітті (Теоретична концептуалізація і наукова проблематика державних фінансів). Львів : Каменяр, 2000. 303 с.

31. Соколовська А. М. Податкова система України: теорія та практика становлення. Монографія. К. НДФІ, 2001. $372 \mathrm{c}$.

32. Юлдашев О. Ще раз про методологію удосконалення державного управління: може, востаннє? Юридичний журнал. 2005. № 9. URL: http://www.justinian.com.ua/article.php?id=1894.

33. Крушельницька Т. А Теоретична сутність і практичне наповнення податкового потоку як об'єкту державного управління. Державне управління: удосконалення та розвиток: електронне наукове фахове видання. Київ. 2015. №3. URL: http://www.dy.nayka.com.ua/.

34. Samuelson P. A. The Pure Theory of Public Expenditures. Samuelson. Review of Economics and Statistics, 1954. Vol. 36. No. 4. P. 387-389. 
35. Рубинштейн А. Я. К вопросу расширения «Чистой теории общественных расходов». Научный доклад. М. Институт экономики РАН. 2007. 55 с.

Information about the author:

Krushelnytska Taisiia,

Doctor of Public Administration, Associate Professor, Professor at the Department Economy and Regional Economic Policy, Dnipropetrovsk Regional Institute of Public Administration, National Academy of Public Administration of the President Ukraine 29, Gogolia str., Dnipro, 49044, Ukraine 